\title{
PERUBAHAN LUASAN LAHAN MANGROVE SEBAGAI RUANG TERBUKA HIJAU DI WILAYAH PESISIR KOTA BANDAR LAMPUNG
}

\section{CHANGES IN THE MANGROVE AREAS AS OPEN GREEN SPACE IN THE COASTAL AREA OF BANDAR LAMPUNG CITY}

\author{
Maurent Kartika Maharani' ${ }^{1}$ Indra Gumay Febryano, ${ }^{1,2}$ \\ Novita Tresiana ${ }^{3}$, Irwan Sukri Banuwa ${ }^{1}$
}

\author{
${ }^{1}$ Jurusan Kehutanan, Fakultas Pertanian, Universitas Lampung \\ ${ }^{2}$ Manajemen Wilayah Pesisir dan Laut, Program Pascasarjana, Universitas Lampung \\ ${ }^{3} J u r u s a n$ Administrasi Publik, Fakultas Ilmu Sosial dan Ilmu Politik, Universitas Lampung \\ Jl. Prof. Dr. Soemantri Brojonegoro No. 1, Bandar Lampung Indonesia
}

Email: maurentkartika@gmail.com

\begin{abstract}
ABSTRAK
Wilayah pesisir memiliki banyak fungsi seperti fisik, ekologi, dan ekonomi dengan keberadaan mangrove didalamnya. Penelitian ini bertujuan untuk mengetahui perubahan luasan mangrove yang berada di Kota Karang. Metode yang digunakan yaitu teknik interpretasi citra dengan Sistem Informasi Geografis (SIG) terhadap perubahan luasan tahun 2012, 2015, 2017, dan 2019. Data perubahan luasan mangrove selanjutnya di analisis dengan hasil wawancara secara langsung terhadap perubahan luasan yang terjadi untuk mengetahui penyebab perubahan luasan lahan mangrove. Hasil penelitian menunjukkan pada tahun 2015 terdapat penurunan luasan mangrove seluas 0,4781 ha karena pengembangan wilayah pesisir menuju Pulau Pasaran. Tahun 2017-2019 peningkatan terjadi karena kemampuan mangrove menyesuaikan diri dengan habitatnya sehingga luasan meningkat ke arah lautan seluas 1,139 ha. Peningkatan luasan mangrove di wilayah pesisir perkotaan dapat dipertimbangkan untuk ditetapkan sebagai Ruang Terbuka Hijau disamping wilayah Konservasi Pesisir dan Pulau-Pulau Kecil.
\end{abstract}

Kata kunci : Manajemen Pesisir, Sistem Informasi Geografis, Ekowisata, Konservasi

\begin{abstract}
Coastal areas have many functions such as phisical, ecological, and economic with the existence of mangrove inside. The objective of the study is to find out the changes in mangrove area in Karang City. The method which is used in this study is the image interpretation tecnique with Geographic Information System (GIS) to the changes in area in 2012, 2015, 2017, and 2019. The data of mangrove's extensive changes are analyzed by the result of direct interview on the changes in area that occur to find out the cause of the changes in mangrove area. The result shows that in 2015, there was a decrease in mangrove area of 0.4781 ha due to the development of coastal area to Pasaran Island. In 2017-2019, the increase occurred due to the ability of Mangroves to adapt with their habitat so that area increased towards the ocean of 1,193 ha. The increase of mangrove in the urban coastal areas can be considered to be designated as a green open space in addition to coastal conservation area and small islands.
\end{abstract}

Keywords : Coastal Management, Geographic Information System, GIS, Ecotourism, Conservation

\section{PENDAHULUAN}

Daerah pesisir dicirikan dengan eksosistem mangrove karena memiliki nilai yang dipandang oleh berbagai aktor pengembang lahan yang memiliki insentif untuk mengakses kawasan tersebut (Febryano et al., 2014). Ciri khas ekosistem mangrove memiliki produktivitas tinggi serta wilayahnya berdampak langsung bagi makhluk hidup di daratan maupun lautan (Ferreira \& Laceida, 2016). Habitat mangrove memiliki kekhasan karena terletak di sepanjang pantai atau muara sungai dan dipengaruhi pasang surut air laut (Nababan et al., 2016).

Fungsi mangrove dapat dilihat dari berbagai fungsi yaitu secara fisik, ekologi, 
dan sosial ekonomi. Mangrove secara fisik dapat menyerap karbon di permukaan bumi tiga kali lebih tinggi (Bhomia et al., 2016) sehingga dapat memitigasi perubahan iklim secara global (Cameron et al., 2019). Secara ekologi mangrove memiliki fungsi sebagai habitat alami bagi makhluk hidup laut (Junialdi et al., 2019); (Febryano et al., 2014), dan tempat untuk pemijahan dan pengasuhan biota laut (Roy, 2016). Mangrove dapat dijadikan sebagai kayu bangunan, kayu bakar (Junialdi et al. 2019), melestarikan hubungan sosial masyarakat sekitar (Latupapua et al., 2019), dan meningkatkan sikap partisipasi terhadap konservasi mangrove (Desmania et al., 2018) sehingga fungsi sosial ekonomi berkaitan langsung dengan masyarakat yang hidup di sekitar ekosistem mangrove.

Penyebab utama berkurangnya Iuasan hutan mangrove umumnya karena meningkatnya pertumbuhan penduduk yang tinggi di wilayah pesisir (Pattimahu, 2016). Pembangunan di wilayah sekitar mangrove khususnya yang berada di kawasan perkotaan yang mementingkan aspek sosial dan ekonomi dibandingkan aspek lingkungan (Ambinari et al., 2016). Akibatnya penurunan luasan hutan mangrove meningkat secara signifikan.

Perubahan luasan mangrove yang berada di wilayah pesisir perkotaan dapat dikurangi dengan menerapkan pengetahuan masyarakat sekitar tentang pentingnya keberadaan ekosistem mangrove di pesisir perkotaan (Siahaya et al., 2016). Tekanan ini mendorong kawasan perkotaan untuk melakukan peningkatan konversi lahan yang diperuntukkan sebagai kawasan ruang terbuka hijau (Afriyanie et al., 2020). Berdasarkan masalah yang terjadi, penelitian ini bertujuan untuk menganalisis perubahan luasan lahan di kawasan mangrove Kelurahan Kota Karang Bandar Lampung. Penelitian ini bermanfaat untuk dapat memberikan rekomendasi kebijakan terhadap pengelolaan mangrove di wilayah pesisir perkotaan agar ditetapkan sebagai Ruang Terbuka Hijau (RTH).

\section{METODE PENELITIAN}

Penelitian ini dilakukan pada September-Desember 2020 di Kelurahan Kota Karang, Kota Bandar Lampung. Alat yang digunakan adalah GPS (Geographic Positioning System), kamera, dan laptop yang dilengkapi dengan software ArcGis 10.3, Google Earth, dan Microsoft Office. Data yang digunakan dalam penelitian ini adalah citra satelit Google Earth perekaman tahun 2012,2015, 2017, dan 2019 dan Peta Rupa Bumi Indonesia.

Pengumpulan data dilakukan dengan pengamatan menggunakan aplikasi ArcMap 10.3 dengan melakukan teknik digitasi berdasarkan hasil citra pada tahun 2012, 2015, 201, dan 2019. Tahap pengelolaan data citra dilakukan dengan beberapa tahapan menurut Putiksari et al. (2014) seperti pada Gambar 1. Analisis data selanjutnya dilakukan observasi/pengamatan langsung di lapangan, serta wawancara terkait perubahan lahan mangrove di Kota Karang. Wawancara ini dilakukan untuk mengetahui secara mendalam perubahan luasan lahan dan mencari tahu penyebab perubahan tersebut.

Analisis data dalam penelitian dilakukan dengan teknik analisis data secara digital dengan menggunakan teknik overlay peta citra kondisi tahun 2012 dengan citra kondisi tahun 2019 untuk mendapatkan data perubahan luasan lahan mangrove yang terjadi di Kota Karang Bandar Lampung rentang tahun 2012-2019.

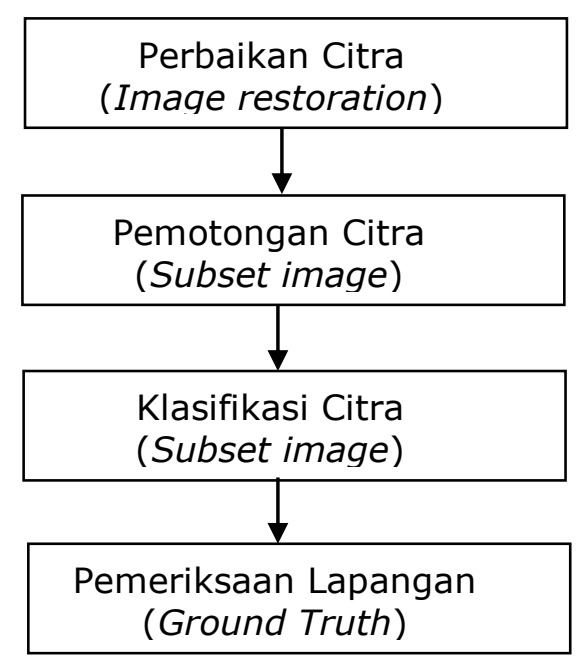

Gambar 1. Tahapan pengelolaan data citra

\section{HASIL DAN PEMBAHASAN}

Kelurahan Kota Karang merupakan kawasan pesisir di Kota Bandar Lampung yang memiliki ekosistem mangrove yang menutupi hampir sepanjang garis pantai yang berada di Kota Bandar Lampung pada tahun 1990 (Kurnia \& Hasanah, 2016). Kota Karang berasal dari bahasa Lampung yaitu Kuta Kakhang yang memiliki arti sebagai pagar Karang. Pagar Karang memiliki artian pada zaman dahulu kelurahan ini terletak di pinggit pantai Teluk Lampung. Pada saat itu Teluk 
Lampung menjadi tempat bersandar para Bajak Laut, sehingga pengamanan dilakukan dengan batu karang. Kota Karang dimekarkan menjadi dua kelurahan pada tanggal 17 September 2012. Pemekaran ini didasarkan Peraturan Daerah Nomor 04 Tahun 2012 menjadi Kota Karang dan Kota Karang Raya.

Kota Karang Terletak di antara $105^{\circ} 15^{\prime} 25^{\prime \prime}$ BT sampai dengan $105^{\circ} 15^{\prime} 55^{\prime \prime}$ BT

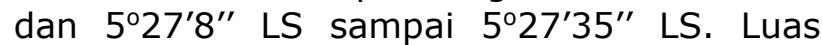
kelurahan mencapai 35 ha dengan jumlah penduduk sebanyak 10.895 orang/Jiwa dan jumlah 2.701 Kepala Keluarga. Penduduk Kelurahan Kota Karang memiliki pendapatan yang berasal dari perikanan, perdagangan, jasa, dan industri rumah tangga. Kota Karang memiliki ciri khas yaitu didominasi oleh suku Bugis.

Komunitas mangrove yang berada di Kelurahan Kota Karang berada dalam kondisi memprihatinkan. Pemukiman banyak dibangun di atas substrat lumpur tempat habitat mangrove. Pemukiman ini terbangun karena desakan kebutuhan pemukiman namun lahan yang semakin berkurang. Jenis mangrove yang terdapat di Kelurahan Kota Karang terdiri atas Avicennia alba, Avicennia marina, Avicennia germinas, dan Burguria parviflora namun jenis yang banyak ditemukan ialah Avicennia germinans atau bakau Api-Api (Kurnia \& Hasanah, 2016).

\section{Perubahan Luasan Mangrove}

Luasan Kelurahan Kota Karang berdasarkan hasil citra Google Earth dari rentan 2012, 2015, 2017, dan 2019 menunjukkan bahwa terjadi perubahan Iuasan secara fluktuasi. Tabel 1 menerangkan bahwa terjadi perubahan luasan mangrove dalam rentan waktu 2012-2019 dan pada Gambar 2 memperlihatkan bagaimana perubahan luasan lahan yang terjadi di Kelurahan Kota Karang.

Tabel 1. Perubahan luasan mangrove di Kelurahan Kota Karang

\begin{tabular}{ccc}
\hline No & Tahun & Luasan (ha) \\
\hline 1. & 2012 & 4,007 \\
2. & 2015 & 3,589 \\
3. & 2017 & 4,668 \\
4. & 2019 & 5,478 \\
\hline
\end{tabular}

Perubahan luasan lahan mangrove ini didukung dengan hasil observasi di lapangan.
Luasan mangrove yang berada di Kelurahan Kota Karang mengalami peningkatan seperti hasil tafsiran dengan bantuan Google Earth. Pada tahun 1990, mangrove yang berada di kawasan tersebut tumbuh alami namun mangrove tersebut ditebang habis sehingga mangove di lokasi tersebut berkurang luasannya. Penanaman mangrove oleh Walhi (Wahana Lingkungan Hidup Indonesia) tahun 1993 menghasilkan pertumbuhan mangrove skala sedang. Hal ini terjadi karena mangrove tumbuh dengan baik dan menyesuaikan diri dengan habitatnya, sedangkan sebagian mangrove tersebut tidak tumbuh dengan baik.

Kawasan mangrove yang tersisa di wilayah pesisir perkotaan selanjutnya mendapatkan perhatian dari Lembaga Swadaya Masyarakat (LSM). Beberapa LSM yang terlibat ialah Yayasan Akar, Tangan, dan Mahusa. Perhatian ini terwujud di tahun 2015 dengan penanaman bibit. Bibit mangrove yang ditanam di wilayah tersebut sebanyak 10.000 dalam kurun waktu satu tahun. Hasil penanaman menunjukkan mangrove mengalami kematian dan beberapa mangrove yang menyesuaikan diri dengan habitatnya.

Penanaman mangrove dilakukan setiap tahunnya dari berbagai macam LSM dan mulai diperhatikan eksistensinya. Instansi pemerintah yang terlibat dalam kegiatan tersebut yaitu Bappeda (Badan perencanaan Pembangunan Daerah), dan Dinas Kelautan dan Perikanan. Hari besar lingkungan lokasi Kota Karang sering dipilih menjadi kawasan penanaman mangrove. Penanaman yang dilakukan di hari besar lingkungan pelaksanaannya baik namun dibiarkan. Tidak adanya monitoring dan evaluasi kembali terhadap pertumbuhan mangrove yang ditanam di lokasi tersebut. Keberhasilan pertumbuhan mangrove tersebut dapat dilihat dari gambar 1 yang menunjukkan time series dari rentan waktu 2012-2019.

Pada tahun 2012 terlihat bahwa luasan mangrove seluas 4,007 ha merupakan hasil penanaman yang dilakukan pada tahun 1993. Peningkatan luasan mangrove pada tahun 2015 memperlihatkan mangrove tumbuh dengan ke arah lautan namun mengalami penurunan luasan sebesar 0,418 ha. Mulai tahun 2015 menuju 2019 terdapat penambahan Iuasan. Penambahan Iuasan ini menurut Pimple et al. (2020) dapat terjadi karena tegakan mangrove alami berpotensi dan berperan sebagai sumber untuk propagul yang dibutuhkan oleh mangrove. Propagul merupakan buah mangrove dimana dapat 
tumbuh apabila terlepas dari indukan mangrove dan jatuh ke lantai hutan atau substrat mangrove (Pribadi et al., 2014). Hal ini yang menyebabkan luasan mangrove dapat bertambah secara alami.

Jenis mangrove yang berada di Kelurahan Kota Karang merupakan jenis ApiApi (Avicennia). Mangrove berjenis Avicennia umumnya berada dalam zonasi pinggir sungai (riveriae) yang memiliki ciri khas tergenang hanya saat pasang purnama, salinitas berkisar antara 0-10 ppt dengan tipe berdebu-liat berdebu sampai liat (Kusmana et al. (2005); Khairijon \& Sofiyanti, (2015). Avicennia tumbuh di lokasi substrat berlumpur. Substrat ini berasal dari penggalian muara sungai di Kota Karang. Hal ini membuktikan penanaman yang dilakukan di kawasan mangrove hanya jenis Avicennia yang bertahan dan tumbuh dengan baik.

Penurunan luasan mangrove tahun 2015 terjadi karena terdapat aktivitas penebangan. Mangrove ditebang apabila menutupi jalan sekitar. Penebangan juga dilakukan diduga mangrove sebagai sumber sarang nyamuk. Putra et al. (2015) menjelaskan bahwa sanitasi yang berada di lokasi mangrove dalam kondisi baik maka mampu memusnahkan habitat nyamuk yang keluar dari mangrove menuju pemukiman. Pendapat ini sejalan dengan kondisi lokasi dimana sanitasinya kurang baik Penyebab penurunan lainnya didukung adanya pembangunan fasilitas publik. Pembangunan jembatan menuju Pulau Pasaran yang memotong kawasan mangrove menuju lokasi pembangunan menyebabkan kawasan mangrove ini mengalami penurunan secara signifikan.

Kawasan mangrove di tahun 2017 dan 2019 mengalami peningkatan luasan. Faktor yang menyebabkan peningkatan luasan lahan mangrove ini ialah dimulai pada tahun 2017. Terdapat penanaman yang dilakukan LSM yang menemukan bahwa Kota Karang memiliki ekosistem mangrove yang tersisa di Pesisir Perkotaan. LSM yang melirik bahwa mangrove di Kota Karang merupakan kawasan konservasi. Pada perayaan hari besar lingkungan banyak LSM memilih penanaman di lokasi mangrove Kota Karang.

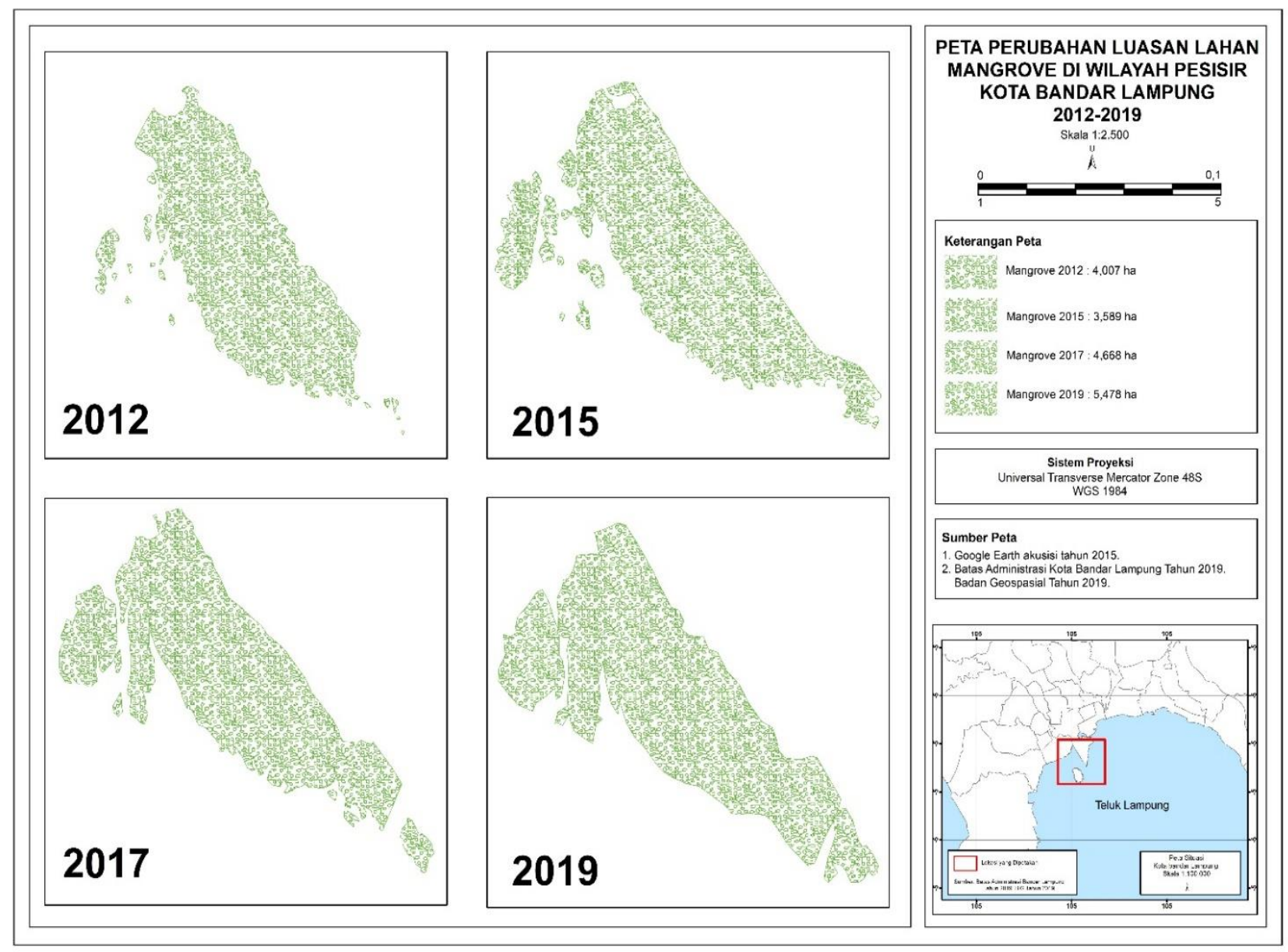

Gambar 2. Keberadaan mangrove di Kelurahan Kota Karang tahun 2012, 2015, 2017, dan 2019. 
Tidak adanya proses monitoring dan evaluasi terhadap penanaman mangrove menyebabkan banyak mangrove mati. Kematian ini karena tidak sesuainya jenis habitat mangrove yang ditanam. Penanaman mangrove jenis Rhizopora sp marak ditanam, hanya sedikit LSM yang menanam jenis Avicennia sp. Meskipun terlihat jenis yang sesuai dengan habitat ialah Avicennia sp. Peningkatan luasan mangrove memberikan harapan tentang penetapan kawasan mangrove yang berada di Kota Karang dijadikan sebagai Ruang Terbuka Hijau yang wacananya telah disebutkan oleh Walikota Bandar Lampung.

\section{Kebijakan Ruang Terbuka Hijau (RTH) Mangrove}

Kawasan mangrove yang berada di Kota Karang merupakan mangrove terakhir yang tersisa di wilayah pesisir perkotaan Bandar Lampung. Eksistensi keberadaan mangrove tersebut kemudian diatur dalam beberapa peraturan tingkat daerah. Peraturan ini mengatur tentang zonasi wilayah mangrove. Terciptanya kebijakan untuk mencapai sinergi koordinasi dalam kebijakan di lapangan (Salminah \& Aliviya, 2019). Kebijakan pengelolaan mangrove dilakukan untuk memberikan tekanan dan dorongan bagi aktor yang terlibat (Febryano et al., 2015).

Kebijakan yang dikeluarkan oleh implementer kebijakan dimuat dalam Peraturan Daerah Provinsi Lampung Nomor 1 tahun 2018 tentang Rencana Zonasi Wilayah Pesisir dan Pulau-Pulau Kecil Provinsi Lampung Tahun 2018-2038. Tahun berikutnya terbitlah Peraturan Gubernur Lampung Nomor 20 Tahun 2019 tentang Pengembangan Kawasan Konservasi Perairan dan Kawasan Konservasi Pesisir dan PulauPulau Kecil Provinsi Lampung. Kedua peraturan ini memuat bahwa kawasan mangrove di Kota Karang masuk dalam Kawasan Konservasi Pesisir dan Pulau-Pulau Kecil (KKP3K). Secara tata ruang diatur dalam Peraturan Daerah Kota Bandar Lampung Nomor 10 tahun 2011 bahwa mangrove sebagai kawasan lindung.

Rencana pembangunan Pulau Pasaran menjadi ekowisata memicu wacana mangrove dijadikan Ruang Terbuka Hijau oleh Walikota bandar Lampung. Wacana ini diketahui oleh para pamong Kelurahan Kota Karang yang menyetujui wacana tersebut. Masyarakat setuju terlihat dari aktivitas yang dilakukan. Mereka tidak merusak kawasan mangrove dan menerapkan aturan. Aturan ini sifatnya tidak tertulis yaitu larangan untuk menebang mangrove. Mereka mengerti bahwa mangrove merupakan tanaman yang harus dilindungi keberadaannya. Mereka percaya mangrove memiliki beberapa manfaat, meskipun para implementer belum pernah melakukan sosialisasi terkait manfaat mangrove bagi masyarakat.

RTH penting untuk dimiliki bagi wilayah perkotaan yang ada di Indonesia. Menurut Undang-Undang No. 26 Tahun 2007 tentang Penataan Ruang, wilayah perkotaan harus menyediakan RTH sebesar $30 \%$ dari luasan wilayah kota. RTH dibagi menjadi RTH privat dan RTH publik. Fungsi dari tersedianya RTH di wilayah perkotaan untuk mengatur iklim mikro, menyerap air hujan (Immacculata et al. (2017); Sapariyanto et al. (2016), mengurangi polusi udara (Marshall et al., 2019), dan meningkatkan oksigen karena dapat menerap emisi $\mathrm{CO}_{2}$ (Humaida et al., 2016). Meningkatkan ketersediaan RTH perlu dilakukan untuk mengalisa kondisi yang berkaitan dengan kualitas lingkungan, fungsi ekologi, fisik, serta ekonomi di ruang terbuka hijau dengan kesejahteraan masyarakat sekitar (Nurbaya et al., 2016).

Solusi peningkatan kualitas lingkungan di wilayah perkotaan dapat dilakukan dengan menetapkan RTH yang wilayahnya termasuk kawasan lindung (Ulfa \& Fazriyas, 2020). Hutan mangrove dapat menjadi salah satu opsi karena memiliki fungsi yang mendukung peningkatan RTH. Bentuk tata kelola yang dilakukan dapat berupa ekowisata. Tresiana dan Duadji (2018) menyatakan bahwa ekowisata dapat dilihat sebagai pasar yang diarahkan sebagai upaya pelestarian lingkungan. Upaya ini didukung dengan pengembangan pariwisata berbasis komunitas masyarakat (Tresiana \& Duadji, 2017). Melalui hal ini, masyarakat dapat terlibat dalam pengelolaan mangrove sebagai ekowisata untuk meningkatkan RTH.

\section{KESIMPULAN}

Luasan mangrove yang berada di Kelurahan Kota Karang dengan rentan waktu 2012-2019 mengalami perubahan luasan secara fluktuatif. Penurunan luasan mangrove disebabkan pembangunan infrastruktur yang memotong kawasan mangove seluas 0,4781 ha. Peningkatan luasan mangrove naik 1,139 ha disebabkan mangrove tumbuh alami ke arah laut. Hal ini mendukung kawasan mangrove meningkat luasannya. Kondisi ini dapat menjadi pertimbangan agar kawasan mangrove dijadikan sebagai RTH. 


\section{DAFTAR PUSTAKA}

Afriyanie, D., Julian, M.M., Riqqi, A., Akbar, R., Suroso, D.S.A., \& Kustiwan, I. 2020. Re-framing urban green spaces planning for flood protection through socio-ecological resilience in Bandung City, Indonesia. Cities. 101:1-20. DOI: 10.1016/j.cities.2020.102710.

Ambinari, M., Darusman, D., \& Alikodra, H.S., Santoso, N. 2016. Penataan peran para pihak dalam pengelolaan hutan mangrove di perkotaan: Studi kasus pengelolaan hutan mangrove di Teluk Jakarta. Jurnal Analisis Kebijakan, 13(1):29-40.

Bhomia, R.K., Kauffman, J.B., \& Mcfadden, T.N. 2016. Ecosystem carbon stocks of mangrove forests along the Pacific and Caribbean coast of Honduras. Wetlands Ecological Manage. 24:187-201. DOI 10.1007/s11273-016-9483-1.

Cameron, C., Hutley, L.B., Fries, D.A., \& Brown, B. High greenhouse gas emissions mitigation benefits from mangrove rehabilitation in Sulawesi, Indonesia. Ecosystem Services. 40: 101035. DOI: $10.1016 / \mathrm{j}$.ecoser.2019.10 1035

Desmania, D., Harianto, S.P., \& Herwanti, S. 2018. Partisipasi Kelompok Wanita Cinta Bahari dalam upaya konservasi hutan mangrove. Jurnal Sylva Lestari. 6(3):28-35.

Febryano, I.G., Suharjito, D., Darusman, D., Kusmana, C., \& Hidayat. 2014. The roles and sustainability of local institutions of mangrove management in Pahawang Island. Jurnal Managemen Hutan Tropika. 20(2):69-76. DOI: 10.7 226/jtfm.20.2.69.

Febryano, I.G., Suharjito, D., Darusman, D., Kusmana, C., \& Hidayat, A. 2015. Aktor dan relasi kekuasaan dalam pengelolaan mangrove di Kabupaten Pesawaran, Provinsi Lampung, Indonesia. Jurnal Analisis Kebijakan Kehutanan. 12(2):125-142.

Ferreira, A.C., \& Lacerda, L.D., 2016. Degradation and conservation of brazilian mangroves, status and perspectives. Ocean Coastal Management. 125(1): 38-46. DOI: 10.1016/j.ocecoaman.2016. 03.011

Fitriyah, D., Arimurti, S., \& Senjarini, K. 2013. Physiological and molecular characteristics of bacterial isolates from Bandealit coastal area Jember, East Java, Indonesia. HAYATI Journal of
Biosciences, 20(2): 89-93. DOI: 10.43 08/hjb.20.2.89.

Humaida, N., Prasetyo, L.B., \& Rushayati, S.B. 2016. Priority assessment method of green open space (Case study: Banjarbaru City). Procedia Environmental Sciences, 33:354-364. DOI: 10.1016/j. proenv.2016.03.086

Immaculata, M., Sulistyana, D., Yuwono, S. B., \& Rusita. 2017. Kenyamanan Hutan Kota Linara berbasis kerapatan vegetasi, iklim mikro dan persepsi masyarakat di Kota Metro. Jurnal Sylva Lestari, 5(2):78-87.

Khairijon, F., \& Sofiyanti, N. 2015. Analisis vegetasi Avicennia sp. dan karakteristik sedimen di kawasan mangrove Desa Sungai Rawa Kecamatan Sungai Apit Kabupaten Siak, Riau. Jom FMIPA. 2(1): 23-34.

Kurnia, A., A., \& Hasanah, A. 2016. Analisis spasial dan temporal perubahan karakteristik ekosistem mangrove di wilayah pesisir Kota Bandar Lampung. Geo-Environment Student Challenge. 1(1):1-7.

Kusmana, C., Wilarso, S., Hilwan, I., Pamoengkas, P., Wibowo, C., Triyana, T., Triswanto, A., \& Yunasfi, Hamzah. 2005. Teknik Rehabilitasi Mangrove. Fakultas Kehutanan Institut Pertanian Bogor. 181p.

Marshall, A.J., Grose, M.J., \& Williams, N.S.G. 2019. From little things: More than a third of public green space is road verge. Urban Forestry \& Urban Greening. 44:1-13. DOI: $10.1016 /$ j.uf ug.2019.126423

Nababan, E.J.K., Qurniati, R., \& Kustanti, A. 2016. Modal sosial pada pengelolaan dan pelestarian hutan mangrove di Kecamatan Labuhan Maringgai Kabupaten Lampung Timur. Jurnal Sylva Lestari. 4(2):89-100.

Nurbaya, A., Zain, A.F.M., \& Djakapermana, R.D. Study and distribution and slope aspect approach to increase public green open space spacial Capital Region of Jakarta using highresolution imaginery. Procedia Social and Behavioral Sciences. 227: 574-582. DOI: $10.1016 /$ j.sbspro.2016.06.117

Pattimahu, D.V. 2016. Analisis perubahan penutupan lahan mangrove di Kabupaten Seram Bagian Barat Maluku. Jurnal Hutan Pulau-Pulau Kecil, 1(1): 22-27. DOI:10.30598/jhppk.2016.1.1.22.

Pimple, U., Simonetti, D., Hinks, I., Osszwald, Berger, U., Pungkul, S., 
Leadprathom, Pravinvongvuthi, T., Maprasoap, P., \& Gond, V. A history of the rehabilitation of mangroves and an assesement of their diversity and structure using landast annual composite (1987-2019) and transcet plot inventories. Forest Ecology and Management. 462(1):1-17. DOI: 03781127.

Pribadi, R., Muhajirm A., Widianingsih, \& Retno Hartati. 2015. Pemangsaan propagul mangrove Rhizapora sp. sebagai bukti teori dominancepredation. Ilmu Kelautan. 19(2):105112.

Putiksari, V., Dahlan, E.N., \& Prasetyo, L.B. 2014. Analisis perubahan penutupan lahan dan faktor sosial ekonomi penyebab deforestrasi di Cagar Alam Kamojang. Media Konservasi. 19(2): 126-140..

Putra, A.K., Bakri, S., \& Kurniawan, B. 2015. Peranan ekosistem hutan mangrove pada imunitas terhadap malaria: Studi di Kecamatan Labuhan Maringgai Kabupaten Lampung Timur. Jurnal Sylva Lestari. 3(2):67-78.

Roy, A.K.D. 2016. Local community attitudes towards mangrove forest conservation: Lessons from Bangladesh. Marine Policy. 74(1): 186-194. DOI: 10.1016/j.mar pol.2016.09.021
Sapariyanto, Yuwono, S.B., \& Riniarti, M. 2016. Kajian iklim mikro di bawah tegakan ruang terbuka hijau Universitas Lampung. Jurnal Sylva Lestari. 4(3): 114-123. DOI: $10.239609 /$ jsl34114-123.

Siahaya, M.E., Salampessy, M.L., Febryano, I.G., Rositah, E., Silamon, R.F., \& Ichsan, A.C. 2016. Partisipasi masyarakat lokal dalam konservasi hutan mangrove di wilayah Tarakan, Kalimantan Utara. Jurnal Nusa Sylva, 16(1):12-17.

Tresiana, N., \& Duadji, N. 2017. Kolaboratif pengelolaan pariwisata Teluk Kiluan (Collaborative management of the Teluk Kiluan tourism). Seminar Nasional: Membangun Etika Sosial Politik Menuju Masyarakat yang Berkelanjutan. 18 Oktober 2017. 77$84 p$.

Tresiana, N., \& Duadji, N. 2018. Tata Kelola Pariwisata Teluk Kiluan Berkelanjutan. Graha Ilmu. Yogyakarta. 95p.

Trinanda, T.C. 2017. Pengelolaan Wilayah Pesisir Indonesia dalam rangka pembangunan berbasis pelestarian lingkungan. Mitra Pembaruan. 1(2): 7584.

Ulfa, M., \& Fazriyas. Ruang terbuka hijau publik di Kota Jambi berbasis jumlah penduduk dan kebutuhan oksigen. Jurnal Sylva Lestari. 8(3):336-377. 